\title{
B OUNDARIES
}

OF THE

INTERNATIONAL 



\title{
B OUNDARIES \\ OF THE
}

\section{INTERNATIONAL}

\author{
Law and Empire
}

J E N N I F E R P I T T S

\author{
III \\ 11 \\ Harvard University Press \\ Cambridge, Massachusetts \\ London, England \\ 2018
}


Copyright $\odot 2018$ by the President and Fellows of Harvard College

All rights reserved

Printed in the United States of America

\section{First printing}

Cataloging-in-Publication Data available from the Library of Congress

ISBN: 978-o-674-98081-5 (alk. paper)

Cover art: Art: Sir Thomas Roe's Embassy to the Court of Jahangir (oil \& pencil on canvas) by William Rothenstein @ Bradford Art Galleries and Museums, West Yorkshire, UK | Bridgeman Images

\section{Cover design: Lisa Roberts}


For Lucia and Nicholas 
